Lee, R.B. and Guenther, M. (December 1991). Oxens or onions? The search for trade (and truth) in the Kalahari. Current Anthropology 32(5), 592-601. 
by Herbert Fleigl and Grover Maxwell, pp. 23I-72. Minneapolis: University of Minnesota Press.

DANIEL, GLYN. 1967. The origins and growth of archaeology. Baltimore: Penguin.

FRITZ, JOHN, AND FRED PLOG. I970. The nature of archaeological explanation. American Antiquity 35:405-I2.

HEMPEL, CARL G. I962. "Deductive-nomological versus statistical explanation," in Scientific explanation, space, and time. Edited by Herbert Fleigl and Grover Maxwell, pp. 98-I69. Minneapolis: University of Minnesota Press.

HODDER, IAN. I99I. Interpretive archaeology and its role. American Antiquity 56:7-I8.

KAPLAN, ABRAHAM. 1964. The conduct of inquiry. San Francisco: Chandler.

LE BLANC, STEVEN. 1973. "Two points of logic concerning data, hypotheses, general laws, and systems," in Research and theory in current archaeology. Edited by Charles E. Redman, pp. I99-214. New York: Wiley-Interscience.

MILLER, DANIEL, AND CHRISTOPHER TILLEY. I984. Ideology, power, and prehistory. Cambridge: Cambridge University Press.

MORGAN, CHARLES. 1973. Archaeology and explanation. World Archaeology 2:259-76.

SHANKS, MICHAEL, AND CHRISTOPHER TILLEY. I987a. Reconstructing archaeology. Cambridge: Cambridge University Press.

- 1987b. Social theory and archaeology. London: Polity Press.

SPAULDING, ALBERT C. I968. "Explanation in archaeology," in New perspectives in archaeology. Edited by Sally Binford and Lewis Binford, pp. 33-39. Chicago: Aldine.

TUGGLE, DAVID, ALEX TOWNSEND, AND THOMAS RILEY. 1972. Laws, systems, and research designs: A discussion of explanation in archaeology. American Antiquity 37:3-12.

WATSON, RICHARD. I99Ia. Ozymandias, king of kings: Postprocessual radical archaeology as critique. American Antiquity 55:673-89.

- I99 $b$. What the New Archaeology has accomplished. CURRENT ANTHROPOLOGY 32:275-91.

\section{Oxen or Onions? The Search for Trade (and Truth) in the Kalahari ${ }^{1}$}

\section{RICHARD LEE AND MATHIAS GUENTHER} Department of Anthropology, University of Toronto, Toronto, Ont./Department of Anthropology, Wilfrid Laurier University, Waterloo, Ont., Canada. I7 vi $9 \mathrm{I}$

We are deeply disturbed by Wilmsen and Denbow's treatment of our comments on their "Paradigmatic History of San-speaking Peoples and Current Attempts at Revision" (CA 31:489-524). They exhibit an almost de-

I. We thank Eric Wood, Henry Harpending, Pauline Wiessner, David Lee, John Sharp, Allison Brooks, and John Yellen for comments and suggestions. Eric Wood also played a key role in the archives in Windhoek. Brigitte Lau provided valuable historical detail. Jane Davie and Geoff Matthews of the Department of Geography, University of Toronto, drew the maps. We acknowledge the financial support of the Social Sciences and Humanities Research Council of Canada and the Research Grants committees of Wilfrid Laurier and Toronto Universities. monic capacity for line-by-line exegesis of opponents' writings in keeping, one supposes, with the obsession with text and textuality of today's "higher criticism," but the fundamental historical errors to which we drew attention (pp. 509-12) are sidestepped, downplayed, dismissed outright, or covered in a volley of double-talk. This simply will not do. At the risk of being labeled old-fashioned, we continue to insist on the importance of the empirical evidence. Before the debate on the theoretical issues of "revisionism" and "pristinism" can proceed, there is work to be done on the evidentiary bases of these theories.

We will confine ourselves to one critical component of Wilmsen and Denbow's argument: that the !Kung people of the NyaeNyae-Dobe area were entwined in the coils of merchant capital from the mid-I 9 th century on to such an extent that it was only when merchant capital collapsed that they became the hunters and gatherers that they appeared to be when ethnographers reached them in the I95os and '6os. In support of this thesis Wilmsen and Denbow claim to provide evidence for major I9th-century historical figures' intimate association, hitherto unnoted, with the NyaeNyae-Dobe area and its peoples. Their linking of personages such as Charles John Andersson, Axel Eriksson, and Robert Lewis with the area and the implication that previous ethnographers have been unaware of or denied this association is a key element in the legitimation of their work. The problem is that in every instance it is Wilmsen and Denbow who are wrong, in some cases egregiously so. No American historian would last five minutes if he or she claimed that Custer made his last stand at Wounded Knee or placed Washington's crossing on the Potomac, yet it seems that errors of similar magnitude can be blandly perpetrated when the locale is a hitherto obscure region in the African interior.

Not a single historical source places Andersson within $200 \mathrm{~km}$ of the NyaeNyae, ${ }^{2}$ and there is, as we have pointed out (p. 5II), a large body of evidence placing him elsewhere in February I $859 .^{3}$ However, Wilmsen and Denbow (p. 5 19) dismiss our objections here as overlooking Andersson's unpublished diaries, on file in the National Archives in Windhoek, Namibia. Wilmsen attributes to these diaries a sketch map which purports to show this hitherto unknown itinerary, and additionally he considers the reference there to "oxen [and] calabashes" in a "Bushman" village "clear evidence of San cattle" (I989:I I 2) in proximity to the NyaeNyae-Dobe area. We were curious as to why the published material could be so at variance with the unpublished diaries, so through the kindness of Brigitte Lau, the archives' director, herself an eminent authority on Andersson, we

2. This and other distances reported here were measured with a University of Toronto opsimeter on the 1985 United Nations Map of Namibia or on the 1973 Republic of Botswana map of Botswana, both to I: $1,000,000$ scale.

3. One of the Wilmsen's maps of Andersson's putative route (fig. 3.I I), incidentally, is attributed to the wrong source; it comes from Passarge's geographical and geomorphological study Die Kalahari, published in 1904, not his book on Bushmen (I907). 


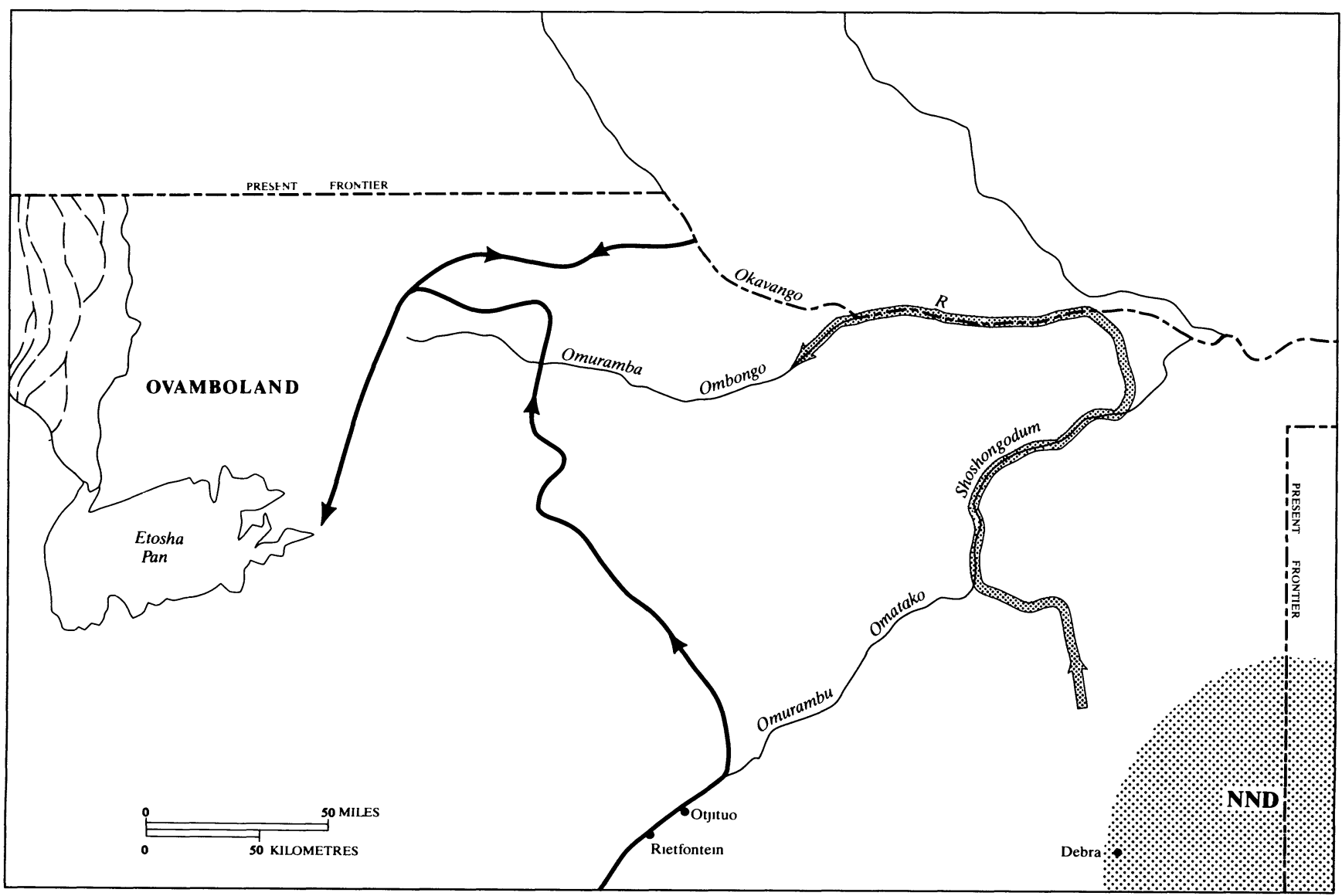

FIG. I. Andersson's route to the Okavango according to Wilmsen (1989) (stippled) and Fisch (I985) (solid).

have obtained facsimile and transcription of the sections of the diaries in question. With even a quick scan of the diaries the Andersson case begins to evaporate. From them it is clear that the word Wilmsen has rendered as "oxen" is "onins," which Lau transcribes as "onions" (personal communication, October 25, 1990). Further, Wilmsen entitles his figure 3.10 (I989:1 I3) "Tracing of a sketch map in Andersson's unpublished diary," but Lau reports that "there is no sketch map of Andersson's I 858/59 route compiled by himself, neither in his original diaries nor in his book" (personal communication, January I8, I99I). ${ }^{4}$ Figure 3.I0 contains a number of mileage estimates that appear to be Andersson's own, but, according to Lau, Andersson "did not as a rule reckon in miles but in hours travelled" (personal communication, January I 8, I991), and he certainly gives no mileage estimates in the passage in question. Where, then, did the sketch map and mileage estimates come from? And what is the status of Wilmsen's claim that Andersson "indeed was very near NyaeNyae"?

To top it off, all of the place-name identifications on the map purporting to be Andersson's are wrong. An-

4. An exception is a two-line sketch in the diaries in which Andersson indicates a change of direction in the Omuramba Ovambo some $300 \mathrm{~km}$ west and entirely unrelated to the NyaeNyae-Dobe. dersson's access route to the Okavango was not the Omatako but the Ombongo, a tributary of the Okavango a considerable distance upriver. This route has been confirmed by all of the I 9 th-century and modern sources on Andersson and additionally has been definitively retraced by Fisch (I985:18), who flatly contradicts Wilmsen's putative route (fig. $\mathrm{I}$ ). ${ }^{5}$

Thus the association of cattle and San and of Andersson and the NyaeNyae-Dobe area is multiply spurious. Andersson was nowhere near NyaeNyae, and finding onions and calabashes together is entirely unremarkable. By compounding errors of both transcription and cartography, Wilmsen transforms the discovery of onions in one part of Namibia into the discovery of cattle in an entirely different part.

Again, the association of Robert Lewis with Lewis-

5. Even if Wilmsen's map were an accurate representation of Andersson's wanderings, his placement of Makgoro would still be about $80-100 \mathrm{~km}$ short of Lee's Mokoro. Another source of error is Wilmsen's arbitrary equation of Andersson's "Reed Ft (Reed fountain)" with Karakobis (Karakuwisa). Rietfontein (from the Afrikaans for "reed fountain)", I65 km farther up the Omatako, is a well-known transit point where I 9 th-century travellers headed north towards eastern Ovamboland, and all the historical sources (including Andersson 1968 [I 86I]) trace Andersson's route through "Rietfontein," not Karakobis. 


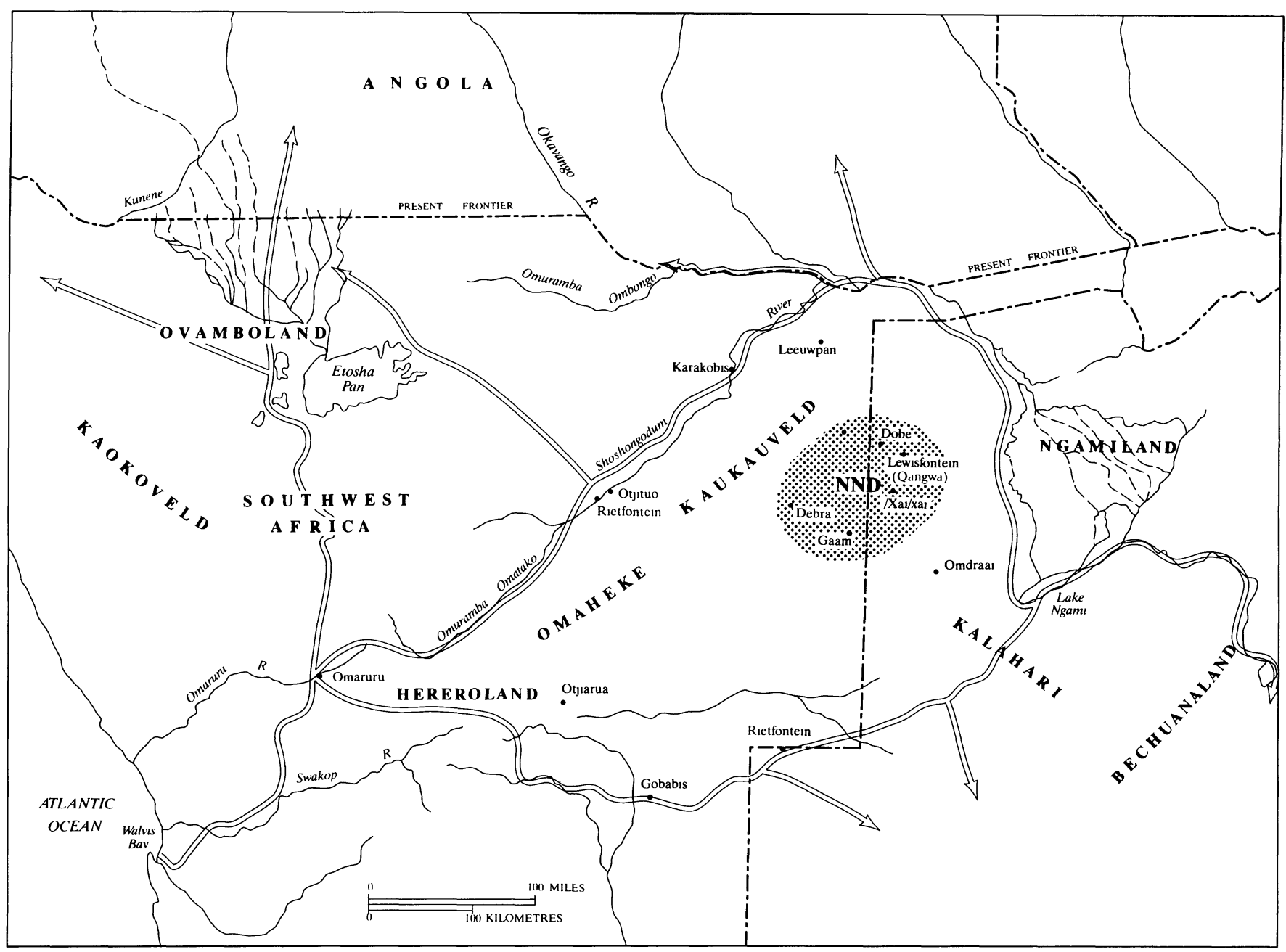

FIG. 2. Place names and trade routes in Ngamiland and South-West Africa, I850-75. NND, NyaeNyae-Dobe.

fontein in $\mathrm{I} 863$ is extremely dubious. Both Wilmsen (I989) and Wilmsen and Denbow (CA 31 ) place Lewis in the Kaukauveld in I863. Yet Tabler (1973:68) records that Lewis "traded and hunted elephants in the Kaokoveld and Ovamboland from mid-I 863 till perhaps I 867." Despite the typographical error in our report of this, knowledgeable students of the area are well aware of the distinction between the Kaokoveld (Kaokaoveld), on the Atlantic coast, and the Kaukauveld, in which Dobe and Qangwa are located, $1,000 \mathrm{~km}$ inland (fig. 2). Thus Wilmsen and Denbow's response (p. 519) misses the point entirely: "Lee wrongly states that Wilmsen places Robert Lewis in the Dobe area in I863; what Wilmsen says is that Lewis was trading in the Kaukauveld (a much larger area of which Dobe is a small part) beginning in I 863." But that is our point: Lewis was nowhere near the Dobe area or the Kaukauveld in 1863 . Further, that there is no evidence to link Lewis with the placename "Levisfontein" they virtually concede in their admission that "Lewis must have been the source of
'Lewisfontein,' although there is no definite proof' (p. 519, emphasis added). ${ }^{6}$

Lewis was indeed a well-known figure in South West African history as "hunter, trader, mine manager, agent, intriguer, politician, concessionaire" (Tabler I973:68), but his main base of operations was in Hereroland, west of NyaeNyae-Dobe, where he was an advisor to Maherero, the Herero paramount chief. He traded and hunted in the eastern regions only sporadically. One additional point: when contemporary Herero at /Xai/xai (CaeCae) express knowledge of Lewis (e.g., Wilmsen I989:I20;

6. J. and P. Landell-Mills state that the place was named after "a member of the Boer trekkers who went to Angola at the end of the last century" (Peters 1972:224). Wilmsen and Denbow reply (p. 519 ) that there were no trekkers with the surname Lewis, but they do not say whether any of the trekkers had the first name Lewis. In any event, since the trekkers did not arrive in the Dobe area until 1876 at the earliest, the naming of Lewisfontein could not have antedated McKiernan's I 877 account by I 5 years as Wilmsen (I989) claimed (see also De Kock I948). 


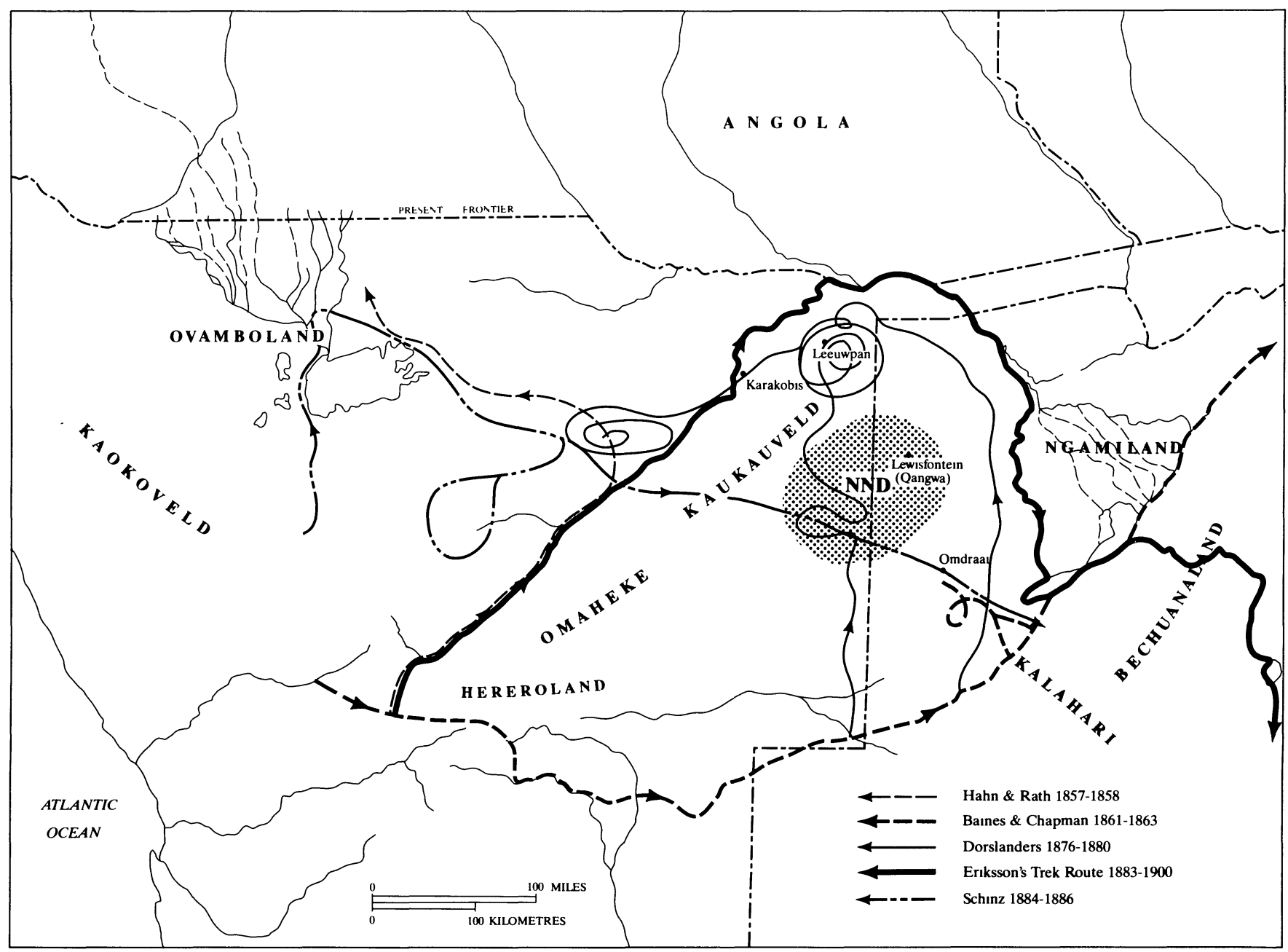

Fig. 3. Routes of exploration and trade of Hahn and Rath, Baines and Chapman, the Dorslanders, Eriksson, and Schinz, I850-I900.

Wilmsen and Denbow, p. 519) it is because their ancestors encountered him in Hereroland; the CaeCae Herero are themselves 2oth-century arrivals in the Dobe area.

As we pointed out (p. 5II), there is no way that Axel Eriksson could have hunted elephants, with or without Lewis, at CaeCae or anywhere else in 1863 ; he did not arrive in the territory until May I $866 .^{7} \mathrm{He}$ went on to become one of the most successful traders in South West Africa, but the great bulk of his trade was in Hereroland, Ovamboland, the Okavango, Angola, the Kunene, and Lake Ngami. Rather than being intimately associated with the NyaeNyae-Dobe area, he went to rather considerable lengths to avoid it. Around 1883 he opened up a trek route for cattle from Hereroland to the Transvaal via Lake Ngami (Winquist I978:69-7I). A direct route

7. Gordon (I 990) has noted a similar error by Wilmsen concerning Andersson's travels. Wilmsen (I989:I09-10) cites Andersson's unpublished diary entry for May 24, I850, concerning his observations of Bushman-Herero amity-a most remarkable accomplishment, says Gordon, "as Andersson only arrived at Walvis Bay at the end of August I850 to commence his travels" (Gordon I990:19). would have gone through the NyaeNyae-Dobe area /see figs. 2 and 3l, but Eriksson took the cattle north down the dry Omatako River to the Okavango, south down it to Lake Ngami, and thence to the Transvaal, making a very wide detour north of the Dobe area and adding at least $350 \mathrm{~km}$ to the journey. If the Dobe area had in fact been the focus of the well-travelled trade routes Wilmsen and Denbow claim, why did Eriksson make such an enormously roundabout and costly trek to avoid it?

The Dorsland Trekkers appear in South West African and Angolan history at many points over a vast landscape, including for a time the NyaeNyae-Dobe area. However, as we have indicated (p. 5II), they were brief sojourners there rather than the standard-bearers of merchant capital. A group of about i 5 families under the leadership of G. A. J. Alberts did spend the two years I 876-77 at Rietfontein, $175 \mathrm{~km}$ south of the Dobe area, and did explore NyaeNyae during that period. But there is no evidence that they spent $\mathrm{I} 8$ months at Tebraa or, for that matter, at any single location in the area (fig. 3).

If the NyaeNyae-Dobe area was the hub of long- 
distance trade from the mid-I 9 th century on, then what are we to make of the fact that, when the main body of trekkers (about Ioo wagons) reached Lake Ngami in September I877, a resident hunter, H. Van Zyl, attempted to prevent them from entering the area, which according to Tabler (I973:6I) he "considered his private hunting veld"? How was it possible for Van Zyl to make this claim of exclusivity as late as I 877 for an area which according to Wilmsen had already been crisscrossed by trade routes and dominated by merchant capital since the I850s and "claimed" by Lewis in I863 (Wilmsen I989:8I)?

Finally, when the main body of trekkers was allowed to go forward, again it bypassed the NyaeNyae-Dobe area and moved up the west side of the Okavango delta to a rendezvous with other trekkers south of the Upper Okavango River. After their July I 878 conclave at Leeupan, $125 \mathrm{~km}$ north of the NyaeNyae-Dobe area, attended by a number of other Europeans (Tabler 1973:3I-34; McKiernan I954:I64-70; Vedder I938:4I8-23), they left the Kaukauveld never to return. We must reiterate that the Dorsland Trekkers were refugees looking to settle and not powerful traders and in 1879-80 were the object of an international relief effort (Tabler 1973:33; Vedder I 938:42I). They emphatically fail to provide any firm evidence of the domination of mercantile networks in the I9th-century NyaeNyae-Dobe area.

We do not dispute that the botanist Hans Schinz passed through the Dobe area; we do object to the inferences Wilmsen and Denbrow draw from that journey. As we have pointed out (pp. 5II-I2), Schinz probably never reached Lewisfontein or Karakobis (fig. 31..$^{8}$ Although we have many problems with Passarge's ethnography, he has proven to be a reliable cartographer, and we are inclined provisionally to accept his placing of Schinz's route (I904:pl. I).

All this is not simply a question of specific individuals' not having been where Wilmsen and Denbow say they were: ${ }^{9}$ except for a few years between I875 and I 880, the evidence for any kind of mercantile activity in the NyaeNyae-Dobe is very sparse. And it would require an enormous stretch of the imagination to see the modest amount of mercantile activity that can be documented as sufficient to destroy a mode of production and leave the peoples of the area destitute.

The first point is forcefully made when we consider an important map (I989:8I, fig. 3.5) in which Wilmsen presents a vision of the NyaeNyae-Dobe area as the centre of a network of trade routes in the mid-Igth century. No fewer than five are drawn radiating from the NyaeNyae-Dobe area, leading one reviewer to note that for the period "there is more trade through XaiXai than

8. A fact fully acknowledged by Wilmsen earlier (I982:99) yet inexplicably forgotten here.

9. Other figures spuriously inserted into the NyaeNyae-Dobe area by Wilmsen and Denbow include Wilkerson, who was shot and killed by the San near the Shoshongo Dum, and Todd, for whom there is no evidence that he ever reached the NyaeNyae-Dobe despite the Herero's having a nickname for him (Wilmsen and Denbow, p. 503; McKiernan 1954:170-7I). anywhere in South Africa" (Harpending I99I:3 I4-I5). Given the absence of documentation for any of these routes, the report in the legend to figure 3.5 that "the heavier lines mark the routes most frequently used by Europeans" (Wilmsen I989:8I) seems particularly gratuitous. ${ }^{10}$ Figure 4 compares Wilmsen's map with a map of trade routes for which documentation actually exists.

Wilmsen and Denbow convey an impression of mercantile activity in the Dobe area that was early, intense, ceaseless, ubiquitous, and transformative, but in fact the earliest account we have been able to discover documenting European trade in the NyaeNyae-Dobe dates from 1876-77 and even here the text in questionMcKiernan (I954) -fails to live up to its billing. Wilmsen writes that "McKiernan records specifically that traders regularly visited such supposedly remote places as Gcam and Tebra" (I989: I 20, emphasis added), but in McKiernan's account (I954:I33, I77) there is no indication that the routes to Gcam and Tebra were in regular use-only that trips were made there in August 1877 and November I 878 .

Since in this case as well as others a reading of the actual texts creates a quite different impression from that conveyed by Wilmsen and Denbow, it would be prudent to treat all of their assertions of mercantile presence with caution. While the question is open just how ubiquitous mercantile activity was, it seems clear that the level of mercantile activity for the NyaeNyae-Dobe area has been vastly overestimated. This point is graphically made by an analysis of the data presented in $\mathrm{Ta}$ bler's (I973) compendium of accounts of all the Europeans known to have explored, traded in, or missionized the large region of which the NyaeNyae-Dobe area is more or less the geographical center. Of 334 individuals and parties who travelled in the interior before 1880 , the number that have any association at all with the area is 9, including Hendrik Van Zyl, his two sons and two associates, the Dorsland Trekkers, and three associates of Charles McKiernan. ${ }^{11}$ McKiernan himself never entered the area. Further, all the visits recorded by Tabler occurred between I 875 and I880, particularly I 877 and I 878 .

For an area seemingly in the thick of the southern African mercantile boom, the NyaeNyae-Dobe area is remarkably unknown and unchronicled in the I9th-century sources, while evidence for its isolation abounds. Examples involving other major figures from the mid-I9th century illustrate this point. We have alrady mentioned Galton's (I97 I [I 853]) report of "a broad land dividing [the Damaras of Hereroland] from the natives to the east" (p. 5I2). In I857, the Reverend C. H. Hahn and Johannes Rath wanted to go from Otjikango

Io. The period covered by this map is not specified, but we assume that the term "mid-nineteenth century" refers to the period 1833-66. The issue is confused, however, because the same map is elsewhere said to refer to the "second half of the nineteenth century" (p. 82).

II. By contrast, the number of people who made the trek from Walvis Bay to Lake Ngami or from there to the Transvaal was I 33 , and many of these made multiple journeys. 


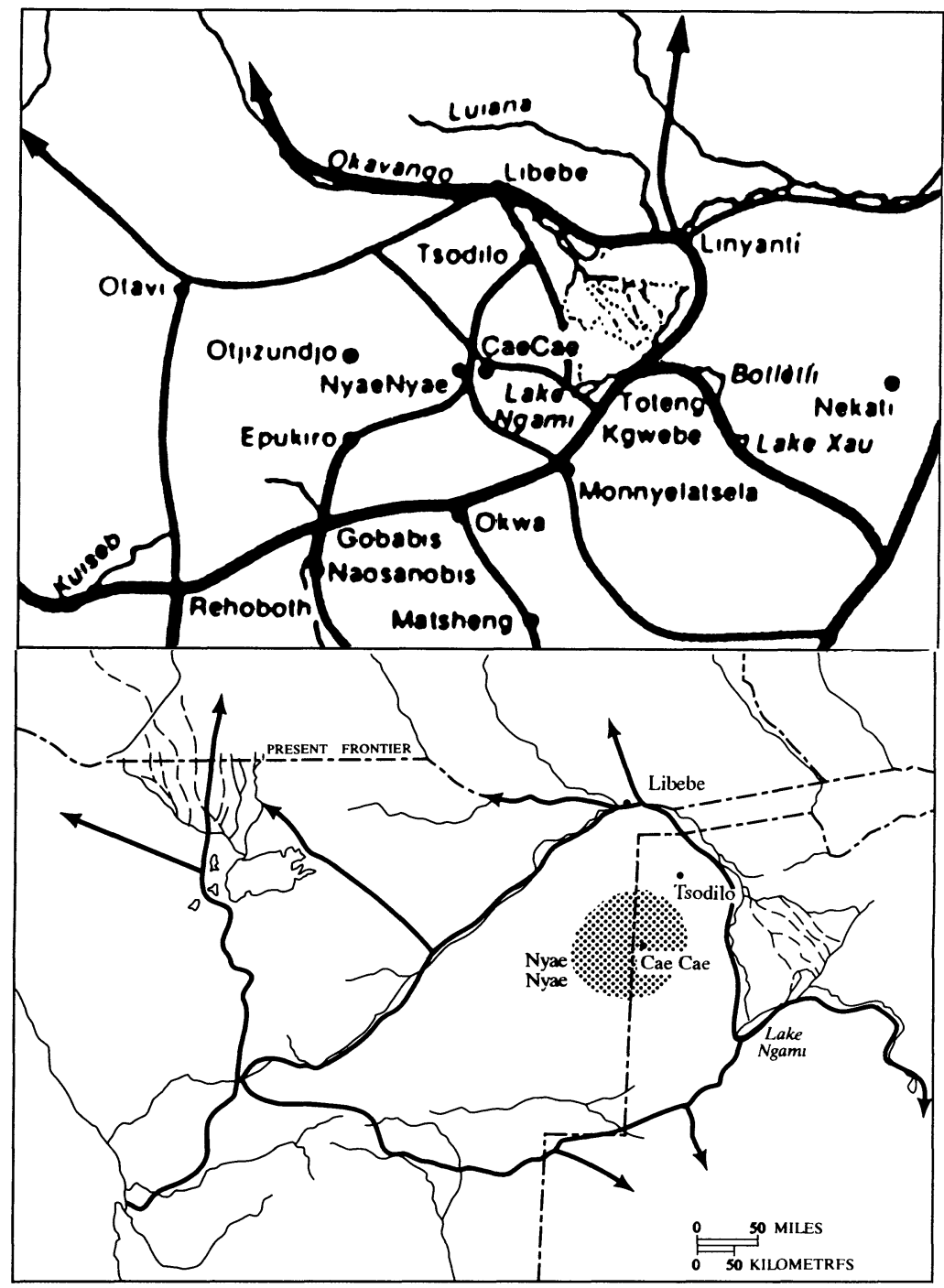

Fig. 4. Mid-Igth-century Kalahari trade routes according to Wilmsen (1989:fig. 3.5) (top) and as compiled from the itineraries of individual travellers documented in Tabler (1973) (bottom). (A more detailed representation of these latter routes will be published elsewhere.)

at the Swakop directly to Lake Ngami along "an as yet untravelled route" (Hahn I980 [I 875]:5) that would have taken them directly through the NyaeNyae-Dobe area, but they never made the trip. Halfway down the Omuramba Omatako, at Otjituo, they met the muchtravelled hunter Frederick Green. He had spent a considerable period hunting elephant up and down the Omatako and, finding that the Omuramba ended in a sandy plain, had decided to move north instead of east (Hahn I980 [I 857]:I6). Upon hearing Green's report the travellers decided on the same course of action (fig. 3). James Chapman and Thomas Baines had a similar experience coming from the other side. In February I 862 the two explorers were trying to return from Lake Ngami to Walvis Bay with a load of ivory. They were seeking a route to the north of Gobabis, where Amraal's Hottentots were harassing traders. However, the lack of a guide, the uncertainty of water supplies, and the threatening attitudes of the local !Kung San caused them to turn back to Omdraii. Had they been successful their route would have taken them through the NyaeNyae-Dobe area, the easternmost settlement of which lay some Ioo $\mathrm{km}$ ahead (Chapman I971 [I868]: I7-32).

The references to the NyaeNyae-Dobe area in the journal of Gerald McKiernan, an American who spent the period I 874-79 in South West Africa, reinforce the sense of remoteness and inaccessibility of the NyaeNyaeDobe. Here in their entirety are the 1877 and 1878 entries referring to the area (McKiernan I954:I32-33, I76-77):

Saturday Aug. 4th [I 877]. Trekked at daylight $\mathrm{I}^{\mathrm{I} / 2}$ hours. Outspanned to let the cattle feed. Inspanned and in $2^{1 / 2}$ hours reached Ghanse [Ghanzi]. Von Zale 
[Van Zyl] a Transvaal Boer is living here. He is now hunting to the north of this, in the Gaam Veltd. Peter, his son, is here; Hendrick Bowers [Bouwer], a hunter, is also here. Mr. Thomas is sick with eresypalus in the face; one of his eyes is closed. Monday Aug. 6. Trading with [young] Von Zale today. Thomas is going to send Lou with Gamble with a cartload of goods, to trade in the Gaam Veltd. They have to load up water for horses to get them in, as there is no water between here and Gaam, six days and nights with wagons. They will also be able to load up enough to give the oxen 2 buckets of water each the 3 rd day.

A year later, in November I878, McKiernan was camped on the Omatako, north and west of the NyaeNyae-Dobe area, when he met two travellers coming out of the area (I954:176-77):

Monday Nov. 25th I 878 . Pete Greyling ${ }^{12}$ passed up yesterday to join his father at the next water above. He saw Lou and Clay to the eastward, but don't know when Lou will return. I am anxious for him to come; we are running short of food and must move soon to where we can find game. . . . Lou came back in the evening; he left Clay to the southeast of this place, on his way to Teabraa Fountain [Debra]. He will go out to Omoruru by Ochaharawa [Otjiarua]. Lou reports plenty of rain in that direction.

The fragmentary recorded history of the igth-century NyaeNyae-Dobe area is marked by one vivid incident that appears in many sources and is remembered with affection by the !Kung themselves (Solway and Lee I990). As Tabler (I973:I I4) reports it:

In July I 877 . . the elder Van Zyl was away, hunting in the Gaam Veld north of Rietfontein. ... H. Van Zyl and his party killed about 400 elephants in the Gaam Veld during 1877 , the yield of ivory being 8000 pounds. His party included two of his sons, Lourens and his sons, and others. They drove a troop of I03 elephants into the thick mud of Oliphants Pan, where the animals bogged down enabling the hunters to kill them all.

The slaughter of elephants notwithstanding, these few passages can hardly be invoked as "irrefutable" evidence that the !Kung San of the NyaeNyae-Dobe area were even regularly visited by traders, let alone involved in merchant capitalism to the point of being "sucked dry of commoditizable wild animals" (Wilmsen I 989:1 27). ${ }^{13}$

By I 885 , when Schinz went through the area, it had become open to trade, and he was able to follow a track. Yet Schinz's testimony offers little or no support for the revisionist view of the area's centrality in the trade. Probably the first trained observer to traverse and to write about the area, Schinz (I 89I) nevertheless provides a disappointing account. There is no ethnographic infor-

I 2. Greyling was a leader of the Dorsland Trekkers.

13. Van Zyl's presence in the Dobe area is hardly a revelation, since Lee has been documenting it since I 965 (e.g., Lee I 965:54-57). mation and little information of any kind about the NyaeNyae-Dobe area proper. However, immediately before making his dash to "Lewisfontein," Schinz did make some observations on the San people he met in the Omaramba Omatako, about $200 \mathrm{~km}$ west of the NyaeNyae and astride a major trade route (p. 357): ${ }^{14}$

The area seemed to be very thinly settled. Nevertheless from time to time we did meet scattered Bushmen hordes. ... The people who visited us at this occasion called themselves the !Kun San, and were evidently from another tribe than those we had met further up the Omaramba. .. . The entire dress of these poor root diggers consists of nothing more than two small furs to cover their private parts and buttocks, and instead of ostrich-eggshell beads their arms and legs are adorned with grass ornaments. The weapons consisted of a hefty throwing stick [and] a medium-sized bow with arrows made of thin Phragmites reed, the poisoned tips of which were made not of iron but of carefully worked bone splinters; which in this part of South West Africa was frequently made of eland antelope.

The picture conveyed here, fragmentary as it is, can be interpreted in several ways. Perhaps the most parsimonious is as evidence for the "Kun San" as representatives of hunter-gatherers not particularly involved in trade (witness the absence of metal arrows). ${ }^{15}$ But one could also see the people encountered by Schinz as impoverished hunters, shattered remnants reduced to penury by the demands of mercantile trade or its passing an explanation that no doubt would be favored by Wilmsen and Denbow. Or with a modicum of ingenuity one could argue that these !Kung were in fact astute traders, only appearing to be poor and concealing their metal weapons and ostrich-eggshell ornaments until the basis for profitable trade could be established. In the absence of compelling evidence, it would be unwise to draw conclusions simply to bolster one or another polemic, and we will refrain from doing so.

Finally we come to Siegfried Passarge, in I897-98 the second trained observer to write about the NyaeNyae-Dobe area and the first to produce detailed geographical knowledge of the area (r 904). Wilmsen and Denbow laud his book on the Bushmen (1907) as "the first

I4. "Das Gebiet schien sehr dünn bevölkert zu sein, dennoch kamen wir von Zeit zu Zeit mit vereinzelten Buschmannhorden zusammen. . . . Die uns hier besuchenden Leute nannten sich !Kun San und waren offenbar von einem anderen Stamme als jene die wir weiter oben gefunden hatten. . . Die ganze Bekleidung dieser armen Wurzelgräber besteht aus nur zwei kleinen Fellen zur Bedeckung der Scham und des Gessäses, anstatt des Perlenschmuckes tragen sie Arm- und Beinringe aus Grasgeflecht. Die Bewaffnung bestand aus einem kräftigen Wurfstock, einem mittelgrossen Bogen mit Pfeilen aus Phragmites-halmen, deren vergiftete Spitzen aber nicht aus Eisen, sondern aus sorgfältig bearbeiten Knochensplittern der in diesem Teile Südwestafrikas häufigen Elanantilopen verfertigt waren."

I 5. Schinz's collection for the Zurich Museum has recently been curated (Szalay I 979) with good-quality photos of the bone arrowheads. Much of the collection could be duplicated in collections made by Lee and others in the r 960 . 
ethnographic account on a San-speaking people." Much has been made by authors and critics of Passarge's politics and racist views and whether these disqualify his observations. We do not believe that they do. What does bear emphasizing, however, is Wilmsen and Denbow's misappropriation of Passarge's writing on one ethnographic area for application to another. As we have indicated (p. 5Io), Passarge's ethnography is not about the !Kung [Zhu] of the NyaeNyae-Dobe but about the //aikwe (or Nharo) of the Chansefeld (or Ghanziveld) and, secondarily, the $\neq$ Aukwe (or $\neq \mathrm{Au} / \mathrm{ei}$ ), !Kungspeakers of the same region. The same applies to the linguistic appendix to the monograph: the section on sentence formation is exclusively on Nharo, and the word lists (in six San languages) feature predominantly Nharo and $\neq$ Aukwe words. Despite some similarities in culture, the Nharo can hardly be taken as an accurate analogue of the !Kung of the NyaeNyae-Dobe.

As did the !Kung, the Nharo defended themselves vigorously from outsiders, but from I850 on they found themselves directly in the path of the major trade route from Walvis Bay to Lake Ngami (fig. 2). Ghanzi became the locus of settlement for dozens of white freebooters and trekkers. Of the nine parties that visited the NyaeNyae-Dobe for brief periods, all had lived in the Ghanzi area for months or years. By Passarge's time the Ghanzi San had already been subject to almost 50 years of intense change, compared with 20 years of more intermittent and (by all accounts) far less traumatic interaction for the NyaeNyae-Dobe !Kung.

Thus, the instances observed by Passarge of Tawana subjugation of San apply, with a couple of exceptions, to "Bushmen" living in the Ghanziveld and around Lake Ngami. As one of us has reported (p. $5 \mathrm{Io}$ ), virtually every anthropologist who has worked in these regions since Passarge has duly noted that the San living there have been subjected to raids and subjugation by either $\mathrm{Ta}$ wana from the east or Khoi (Orlaams) from the west. Whether the Zhu in the more remote NyaeNyae-Dobe area were subjugated by Bantu-speakers is a question on which Passarge's work sheds little light.

Similarly, Wilmsen and Denbow's acceptance of Passarge's "invaluable insights" on Nharo San political organization and leadership as an account of $Z h u$ polity is problematic. Again, what Passarge presents "applies to the Bushmen of the Ghanzi veld" (p. I I 5) and thus refers to the political system of the Ghanzi San. It was outlined to him by his Nharo informant Kopach as an item of memory culture. What is described as a wohlorganisiertes Staatswesen (well-organized state form) akin to the Feudalsystem of the Bantu tribes of Africa was a hierarchically segmented political system. Its largest unit, the Volk, was composed of several Stämme (tribes) which, in turn, were composed of Sippen (kindreds). The last was headed by a Familienoberhaupt (headman; Passarge gives the term //aixa) who, along with other headmen, gave allegiance to the Oberhäuptling (Grootkapitain, using Kopach's Dutch term). The Oberhäuptling (or Häuptling; Passarge seems to use the terms "paramount chief" and "chief" synonymously) who ruled over the Chansefeld within the living memory of Kopach was the "mighty $\neq$ Dukuri," oberster Kriegsherr (supreme warlord), and oberster Richter (supreme judge) of the $\neq$ Aukwe. He also was ruler of the //Aikwe, the "worthless people" whom he had recently conquered. Kopach provided Passarge with a legend-like narrative on this Bushman chief which involves a centralized military chieftainship holding outsiders at bay-a view of Nharo history which interestingly contradicts the revisionist belief that the Kalahari San had been subjects of Iron Age overlords since the year Iooo (Wilmsen and Denbow, p. 500). ${ }^{16}$

Passarge then makes the cultural-ecological argument that this relatively complex political system, along with extensive intertribal trade, rested, until I 870, on an economic base of big-game hunting. ${ }^{17}$ The vast herds of game (ungeheuere Herden von Säugetieren), including, as regularly hunted quarry, elephant and rhinoceros, combined with the rich supply of water along the Ghanzi limestone ridge, allowed for hunting on a unprecedented scale. According to Passarge (I907:76-8I) the methods of hunting then employed were much more elaborate than amongst contemporary Kalahari San and the yields far greater. The early Ghanzi San employed dogs and, hunting in groups up to 300 in number, used such techniques as game drives, game fences (sometimes several miles in length), and rows of staked pitfalls running through dry riverbeds (such as the Epukiro in western Ghanzi).

I6. "Das ganze Gebiet zwischen Rietfontein im Westen, der Grootlaagte im Norden, Okwa im Süden und tief ins Sandfeld hinein, am Epukiro entlang, nach Osten, beherrschte er. Sein Sitz war während er Trockenzeit Chanse und 2 Kchautsa W., während der Regenzeit jagdte er an der Grootlaagte. Er war sehr mächtig und hatte stets zahlreiche Buschmänner um sich versammelt. Mein Gewährsmann hatte als Kind mit eigenen Augen sein Arsenal gesehen, d.h. seine Häuser, die mit Speeren und anderen Waffen angefüllt waren. Er war der oberste Kriegsherr. Auf seinen Ruf hatten sich die Buschmänner zu versammeln, und er führte sie gegen benachbarte Stämme. Von den Familien bezog er jährlichen Tribut in Fellen, Elfenbein, Chore-Ketten u.a. Er war auch der oberste Richter, der die Familienzwiste entschied. Solch Zwiste entsprangen meist Morden und Streitigkeiten infolge Verletzung der Gebiets- und Jagdrechte, sowie von Ehebruch. Wiederholt kam es zu inneren Kämpfen, indem einzelne Familien unbotmässig wurden und seinen Befehlen nicht gehorchten. In aller Frühe bei Morgengrauen wurden manchmal ganze Familien ausgerottet, die Uberlebenden entflohen zu benachbarten Stämmen. Die Würde eines Oberhäuptlings war damals erblich und die Buschmänner völlig unabhängig. Die Batuana wagten sich nicht in ihr Gebiet hinein, die Hottentotten nur auf Raubzügen" (Passarge I907:I I 5). 17. "Jagd [war] die Hauptsache, nicht das Sammeln, dass man sich reichlich ernähren konnte, wenn auch zuweilen Zeiten der Not kamen, und dass demnach die Grundlagen für ein geordnetes soziales und politisches Leben und eine zahlreiche Vemehrung vorhanden gewesen sein müssen, die heutzutage selbst in den am dichtesten mit Buschmännern bewohnten Gebieten fehlen. Nur wenn wir die Zustände früherer Zeiten im Auge behalten, werden wir. . ihre staatlichen Verhältnisse der Jetztzeit und der Vergangenheit richtig verstehen können. . . . Sie waren ein Jägervolk par excellence. Auf der Jagd bauten sich alle sozialen und wirtschaftlichen Verhältnisse auf, all Gesetze und Rechte, die ganze politische Organisation" (pp. 8I, I I9). 
Passarge does suggest that tribes in other regions of the Kalahari (such as the Kaukauveld, which includes the NyaeNyae-Dobe area), too, had Oberhäuptlinge and presents the names he obtained for contemporaneous $\neq$ Aukwe and Zhu "chiefs." But his treatment of their political organization is restricted to naming the chiefs, and no ethnographic description of any kind is provided. The presence of a Buschmann Reich in the NyaeNyaeDobe region similar to the one found among the $\neq$ Aukwe and the Nharo to the south is thus a matter not of ethnographic observation but of extrapolated conjecture.

Given the sparser supply of game and surface water and the absence, evidently, of game drives and other hunting practices akin to those of the Ghanziveld (Marshall I976:135), it is unlikely that political organization of like complexity would have been found in the Kaukauveld-a point that is corroborated by Dobe-area !Kung oral traditions which speak of strong leaders in the I9th century but not authoritarian ones /and certainly not a single paramount leader). The contrast between the two areas is apparent also in more recent times: among the differences observed in spatial and social organization between the Nharo of Ghanzi and the Zhu of Dobe are a reduced degree of fluidity and mobility, a longer aggregation period, and more institutionalized headmanship among the Nharo (Barnard 1979; Guenther 1986:170; Bleek I928:36-37).

It should be clear from the above that the regions of South West Africa showed variation in San social and political organization, degree or presence of Bantu hegemony, and the importance of I 9 th-century trade-its volume, intensity, and frequency and above all the magnitude of social transformation it effected. The available historical sources show that the NyaeNyae-Dobe area, while far from untouched, was bypassed by the vast majority of mercantile activity, in comparison with adjacent areas such as the Ghanzi area to the south and/ or Damaraland to the west. Distance, isolation, and the !Kung reputation for fierceness probably account in equal measure for the profound ignorance of the !Kung interior on the part of traders and missionaries. Since the attribution of trade routes to the NyaeNyae-Dobe area is critical to Wilmsen and Denbow's arguments, given the apparent paucity of solid information on the area's encounter with merchant capital we must question the status of those arguments.

If indeed Andersson, Lewis, Eriksson, Schinz, and the Dorsland Trekkers had come to the NyaeNyae-Dobe area and left their marks and all this evidence had been ignored or denied by the Harvard Kalahari research group, then their arguments would constitute a powerful case for the revisionist view of the !Kung San. But if none of these matters are as Wilmsen and Denbow claim, then perhaps the spotlight of critical scrutiny needs to be refocussed. Given the misplacement of so many historical figures and the absence of any solid evidence for social transformation, we fail to see how the data that remain support the view that the San of the NyaeNyae-Dobe area had been so deeply involved in trade that they were subsistence foragers in I 897 only because merchant capital had made them that way.

Are we being old-fashioned in insisting that the analysts who invoke the power of merchant capital have an obligation to demonstrate its empirical impact and that this impact is a variable not a constant? Or is empiricism, too, to be labeled "romanticism" and discarded along with the rest of what has been labelled the outmoded project of modernist positivism?

For the revisionists it seems that a society has only two alternatives: complete isolation or virtual domination, with no possibility of defending its interests and interacting and trading without being consumed. Unfortunately, the assumption is very widespread in current anthropology. Assuming the power and reach of capital in turn is related to a failure to understand the logic of communal modes of production - the ability of such societies to reproduce themselves. Instead, the unstated and unexamined assumption is that the minute mercantilism enters the scene it is game-over for the precapitalist society, and any amount of mercantile activity is sufficient to destroy communalism and transform it into something else.

In the past, scholars arguing for the colonial transformation of indigenous peoples used to invoke evidence for traumatic events such as wars, epidemics, enslavement, displacement or forced migration, permanent stationing of military, settlers, or missionaries, the building of railways, or the discovery of mineral deposits. Even under these circumstances groups have been known to resist and survive. In the NyaeNyae-Dobe area there were no wars, no enslavement, no massive die-off, no land grab, no mineral strikes or white-settler encroachment. Yet despite the absence of all of the above and the continuing evidence of !Kung self-reproduction into the I950s and '60s, Wilmsen and Denbow insist that !Kung society was transformed by mercantilism and that "the remoteness imagined by outside observers beginning with Passarge was not indigenous but was created by the collapse of mercantile capital" (Wilmsen I989:127).

We have argued against this view, despite its neat fit with current predispositions in anthropology and social science generally. ${ }^{18}$ NyaeNyae-Dobe remained throughout the period one of the more isolated parts of southwestern Africa. It was far off the beaten track in the I 850 S and I 8600 ; it enjoyed a brief and intense period of activity between 1875 and I 880 , and thereafter the record is largely silent on mercantile activity in the area for the rest of the century. Maps of south-western Africa that bracket the period (e.g., Petermann's maps of I 859 and 1878 ) show the area as a large blank space. When Schinz passed through in 1885 he found timid and shy hunter-gatherers outside the area using bone (not metal)

I8. Nothing presented here is intended to deny that mercantile domination of San and other Kalahari peoples elsewhere was both early and devastating (e.g., Morton I99I, Solway and Lee 1990). Nor does our argument imply that domination by state and other outside agencies was not an increasingly important (and ultimately transformative) feature of !Kung life in the NyaeNyae-Dobe area in the I960s, '70s, and '80s (e.g., Lee and Biesele n.d.). 
arrowheads and wearing minimum ornamentation and mentioned no other ethnic group in the area itself. These observations were confirmed and reinforced by Passarge's more thorough observations in 1897 . It is high time that we abandoned our enchantment with the power and reach of triumphant capital and began to restore to regions like the NyaeNyae-Dobe area their specificity as entities in their own right, with their own internal logics and trajectories, rather than viewing them as simply cat's-paws in some dark morality play about the inevitability of capitalist totality. ${ }^{19}$

\section{References Cited}

ANDersson, C. J. I968 (I86I). The Okavango River: A narrative of travel, exploration and adventure. Cape Town: Struik.

B ARNARD, A. I 979. "Kalahari Bushman settlement patterns," in Social and ecological systems. Edited by P. Burnham and R. Ellen, pp. I3I-44. (ASA Monograph I 8.) London: Tavistock. B LEEK, D. I938. The Naron. Cambridge: Cambridge University Press.

BROOKS, ALISON, M. GUENTHER, H. HARPENDING, R. LEE, AND J. YELLEN. n.d. The past at Dobe. MS.

CHAPMAN, JAMES. I97 I (I868). Travels in the interior of South Africa I 849-1 863. Vol. 2. Cape Town: Balkema.

DE KOCK, W. J. I 948. Robert Lewis of Damaraland. Africana Notes and News 6(I):I4-I 5 .

FISCH, MARIA. I 985 . Ursprung und Bedeutung des Namens Okavango. Journal of the South West African Scientific Society 40/4I:7-28.

GALTON, F. I 97 I (I853). Narrative of an explorer in tropical South Africa. New York: Johnson Reprints.

GORDON, R. I990. Kicking up a Kalahari storm. Southern African Review of Books, February/May, pp. I8-19.

GUENTHER, M. I986. The Nharo Bushmen of Botswana. Hamburg: Helmut Buske Verlag.

- I 990. Comment on: Paradigmatic history of San-speaking peoples and current attempts at revision, by E. Wilmsen and J. Denbow. CURRENT ANTHROPOLOGY 3I:509-IO.

HAHN, C. H. I980 (1857). Entdeckungsreise ins Ovamboland I 857 Tagebuch Carl Hugo Hahn. Edited by Walter Moritz. Aus alten Tagen in Südwest 4 .

HARPENDING, H. I99I. Review of: Land filled with flies, by E. Wilmsen (Chicago: University of Chicago Press, 1989). Anthropos. In press.

LEE, R. B. I965. Subsistence ecology of !Kung Bushmen. Ph.D. diss., University of California, Berkeley, Calif.

- I990. Comment on: Paradigmatic history of San-speaking peoples and current attempts at revision, by E. Wilmsen and J. Denbow. CURRENT ANTHROPOLOGY 3I:5IO-I 2.

19. We have confined ourselves to criticisms of Wilmsen and Denbow's historiography for reasons of space and not at all because we are satisfied with their treatment of other topics. For critiques of the theoretical underpinnings of revisionist views, see Solway and Lee (I 990: 109-I I, I I 9-22, I 42), Lee (n.d.a), and Silberbauer (I991). For discussion of archaeological issues, see Yellen and Brooks (1988, 1990), Lee (n.d.b), and Brooks et al. (n.d.). For critiques of their mistranslations of Herero, !Kung, and German terms, see Guenther (I990) and Harpending (I99I). For a discussion of how the !Kung themselves conceptualize their past and the colonial period, see Lee (n.d.c). n.d.a. Art, science, or politics? The crisis in huntergatherer studies. American Anthropologist 94. In press. . n.d.b. The !Kung in question: Evidence and context in the Kalahari debate. Michigan Discussions in Anthropology Io. In press.

n.d.c. Solitude or servitude? !Kung images of the colonial encounter. Paper presented at the annual meeting of the Canadian Anthropology Society, London, Ont., May.

LEE, R. B., AND M. BIESELE. n.d. Dependency or self-reliance? The !Kung San forty years on. Paper to be presented at the annual meeting of the American Anthropological Association, Chicago, Ill. November.

MARSHALL, L. I976. The !Kung of Nyae Nyae. Cambridge: Harvard University Press.

MCKIERNAN, G. I954. The narrative and journal of Gerald McKiernan in South West Africa, I874-1879. Edited by P. Serton. Cape Town: Van Riebeck Society.

MORTON, F. I99I. Slave-raiding and slavery in the western Transvaal after the Sand River Convention of 1852 . Paper presented at the annual meeting of the Canadian Association for African Studies, Toronto, Ont., May.

PASsARge, s. 1904. Die Kalahari. Berlin: Dietrich Reimer Verlag.

. I907. Die Buschmänner der Kalahari. Berlin: Dietrich Reimer Verlag.

PETERMANN, A. I 859. Reise der Herren Hugo Hahn und Rath im südwestlichen Afrika Mai bis September i 857. Dr. A. Petermanns Mitteilungen aus Justus Perthes Geografischer Anstalt 7:295-303.

- I 878. Herero-Land und Leute. Dr. A. Petermanns Mitteilungen aus Justus Perthes Geografischer Anstalt 8:306-I I.

PETERS, M. 1972. Notes on the place names of Ngamiland. Botswana Notes and Records 4:219-33.

SCHINZ, H. I891. Deutsch-Südwest-Afrika: Forschungsreisen durch die deutschen Schutzgebiete Gross-Nama und Hereroland, nach dem Kunene, dem Ngami-See und der Kalahari, I884-I887. Oldenburg and Leipzig: Schulzesche HofBuchhandlung $u$. Hof-Buchdruckerei.

SILBERBAUER, G. I99I. Morbid reflexivity and overgeneralization in Mosarwa studies. CURRENT ANTHROPOLOGY 32: 96-99.

SOLWAY, J., AND R. LEE. I990. Foragers, genuine or spurious? Situating the Kalahari San in history. CURRENT ANTHROPOLOGY 31:109-46.

SZALAY, M. I979. Die ethnographische Südwestafrika-Sammlung Hans Schinz I884-86. Ethnologische Zeitschrift Zürich $\mathrm{I}$.

TAB LER, E. I973. Pioneers of South West Africa and Ngamiland I738-I880. Cape Town: Balkema.

VEDDER, H. 1938. South West Africa in early times. London: Frank Cass.

WILMSEN, E. I982. "Exchange, interaction, and settlement in north-western Botswana: Past and present perspectives," in Settlement in Botswana. Edited by R. Hitchcock and M. Smith, pp. 98-109. Johannesburg: Heinemann.

. 1989. Land filled with flies: A political economy of the Kalahari. Chicago: University of Chicago Press.

WILMSEN, E., AND J. DENBOW. I990. Paradigmatic history of San-speaking peoples and current attempts at revision. CURRENT ANTHROPOLOGY 31:489-524.

WINQUIST, A. M. 1978. Scandanavians in southern Africa. Cape Town: Balkema.

YELLEN, JOHN, AND ALISON BROOKS. I988. The Late Stone Age archaeology of the !Kangwa and /Xai/Xai Valleys, Ngamiland. Botswana Notes and Records 20:5-27.

- 1990. The Late Stone Age archaeology in the /Xai/Xai region: A response to Wilmsen. Botswana Notes and Records 22:17-I9. 